\title{
The Lesotho Highlands Water Project: Dams, Development, and the World Bank ${ }^{i}$
}

\author{
Robert K. Hitchcock \\ Department of Anthropology, University of New Mexico, USA
}

Copyright (C) 2015 by authors, all rights reserved. Authors agree that this article remains permanently open access under the terms of the Creative Commons Attribution License 4.0 International License

\begin{abstract}
Between 1989 and 2007 the World Bank was one of the funders of the Lesotho Highlands Water Project in southern Africa. This project, which included two large dams (Katse and Mohale), had significant impacts on local people, including loss of grazing, arable land, and resettlement of 71 households in Phase 1A and 325 households in Phase 1B, with a total of 573 people being affected directly, and another 20,000 people affected indirectly (e.g. through loss of natural resources, disruption of travel routes).. Conflicts between LHDA and the World Bank revolved around compensation, resettlement, development, in-stream flow requirements, downstream impacts, the use of project royalties, and the safeguard policies of the World Bank. The impacts of Phase 1 of the Lesotho Highlands Water Project are examined, and an assessment of the LHWP relative to other large-scale infrastructure and resettlement projects in Africa and Asia sponsored by the World Bank and other funding agencies is provided.
\end{abstract}

Keywords Dams, Lesotho, World Bank, Resettlement, Compensation, Development, Cooperatives, Safeguard Policies, Environmental and Social Frameworks

\section{Background}

The Lesotho Highlands Water Project (LHWP) is one of Africa's largest hydroelectric projects. Aimed at supplying water to South Africa and electricity to Lesotho, the LHWP Phase 1, which began in 1986 and was completed in 2009, involved the construction of several large dams and other infrastructure such as roads, bridges, and power lines, the relocation or resettlement of some 400 Basotho households, and the provision of compensation and development programs to local communities affected by the inundation of villages, fields, and grazing lands and losses of natural resources.

One of the funders of the Lesotho Highlands Water Project was the World Bank (the International Bank for Reconstruction and Development), which provided a loan of
US\$45,000,000 to Lesotho (World Bank 2007). This amount represented approximately $3 \%$ of the total project cost. Other funders were the government of Lesotho, the Development Bank of Southern Africa (DBSA), the European Investment Bank (EIB), the African Development Bank, and various commercial banks and institutions.

According to the Lesotho Highlands Development Authority and the Lesotho Highlands Water Commission, the World Bank was approached by Lesotho and South Africa about funding the Lesotho Highlands Water Project for several reasons. First, the governments and the agencies involved in planning the project felt that having the World Bank on board would encourage other potential funding agencies to get involved. Second, the two governments made the argument that Lesotho is a very poor country, with some $55.1 \%$ of the population existing on less than US\$2 a day. They said Lesotho was on the list of the World Bank's lowest-income countries and therefore would qualify for a loan. Third, at least some of the representatives of the two governments felt that having the World Bank support, monitor, and evaluate the project would ensure that the project would seek to follow World Bank guidelines, thus making it more likely to be acceptable to stockholders of companies, non-government organizations, and communities concerned about social, economic, and environmental issues.

Lesotho is a land-locked country in southern Africa; it is slightly smaller than the American state of Maryland, covering an area of $30,355 \mathrm{~km}^{2}$. It is also the southernmost land-locked country in the world. Lesotho is a constitutional parliamentary monarchy that has had complex relations with its giant neighbor, South Africa (Bardill and Cobbe 1986; Ferguson 1994). Lesotho was a member of the front-line states that opposed apartheid in South Africa; as a result, for decades, the country experienced military raids, assassinations, and political and economic pressures. In 1986, after the take-over of the Lesotho government by a military junta, Lesotho signed a treaty with South Africa setting up the Lesotho Highlands Water Project. A major objective of the project was to provide water to South Africa, a water-scarce country, and hydroelectric power to Lesotho, 
which was facing power shortages. Another objective was to reduce environmental degradation in the country, which for decades was considered to be have one of the worst problems of soil erosion of any country in the world (Showers 2005).

The Maluti-Drakensberg Mountains of Lesotho and South Africa can be seen as 'water towers' out of which rivers flow to the foothills and lowlands. Lesotho, sometimes called the Mountain Kingdom, is comprised of so-called highlands, which make up a significant portion of the country (61\%); the foothills, which lie at elevations ranging from 1,800 and 2,200 meters, make up $15 \%$ of the land area of Lesotho. The lowlands, which average between 1,500 and 1,800 meters in elevation, comprise about a fifth of the country $(20 \%)$ and are found primarily on the western and northern boundaries of Lesotho. The Senqu River valley makes up 4\% of the total area of Lesotho (Gill 1993; Chenje and Johnson 1994; Chakela 1999).

Cattle, horses, donkeys, and small stock (sheep and goats) are raised in various parts of the country, with the mountains serving as summer grazing areas for herds from the lowlands and foothills. Cash income is derived from sales of livestock and grain and from migrant labor work in the mines of South Africa (Devitt 1966; Murray 1981; Ferguson 1994). Some $99 \%$.of the population of Lesotho is made up of Basotho, $0.3 \%$ are other Africans or Europeans, and less than $0.1 \%$ claim San ancestry. The population of Lesotho in 2014 was 1,942,008. 40\% of the country's Gross Domestic Product (GDP) is derived from remittances from people working in South Africa, mainly adult males.

The purpose of LHWP Phase 1 was to transfer water from the headwaters of the Gariep River (called the Senqu in Lesotho) to the Vaal river catchment in South Africa and on to the commercial and industrial heartland in Gauteng. Besides water transfer, the LHWP was also aimed at providing hydroelectric power to Lesotho. Phases 1A and 1B of the project, implemented between 1987 and 2008, saw the development of various kinds of infrastructure including roads, power lines, administrative and engineering facilities, dams, and tunnels.

Phase $1 \mathrm{~A}$, constructed at a cost of approximately R20 billion, included the construction of a large dam at Katse on the Malibamatso river, the highest dam in Africa at $180 \mathrm{~m}$, a $45 \mathrm{~km}$ transfer tunnel to 'Muela hydropower station and 'Muela tail-pond, and a further $37 \mathrm{~km}$ delivery tunnel to the Ash River in South Africa

Phase 1B included the Mohale Dam, the highest rock-filled dam in Africa at $145 \mathrm{~m}$, and the Mohale Reservoir, located on the Senqunyane River. There is also a $32 \mathrm{~km}$ tunnel connecting the Mohale Reservoir to the Katse Reservoir, and a weir at Matsoku near 'Muela on the Matsoku River, from which there is a $5.6 \mathrm{~km}$ transfer tunnel to the Katse Reservoir. The $72 \mathrm{MW}$ hydropower station at 'Muela connects with the southern African power pool and provides Lesotho, greenhouse gas free, with its electricity needs.

The Lesotho Highlands Water Project provided for compensation, resettlement, and development initiatives aimed at ensuring that project-affected people will be "enabled to maintain a standard of living not inferior to that obtaining at the time of first disturbance" (Government of Lesotho and Government of South Africa [1986] Lesotho Highlands Water Project Treaty, Article 7, paragraph 18). Compensation is done both in kind (in the form of grains and pulses) and in cash. Houses, schools, and churches were replaced, and payments were made for losses of other assets, including brush wood, trees, thatching grass, and stones used for construction. In addition, communal compensation was paid in the form of cash to community co-operatives or local legal entities (LLEs) both upstream and downstream of the dams.

In the 1980s and 1990s the World Bank arguably had some of the most comprehensive guidelines on how to go about doing resettlement and ensuring environmental and social protection as development projects are implemented (World Bank 2001, 2005). The problem with these guidelines was that they call for the restoration of livelihoods of people affected by projects, but they do not argue for improvement of the standards of living of people who have been affected by projects. The World Commission on Dams (2000) argued for the need to improve the livelihoods of project-affected people as well as those downstream of the project.

While non-government organizations such as International Rivers (formerly International Network, IRN), the Highland Church Action Group (HCAG), and the Transformation Resource Center (TRC) and members of the Panel of Environmental Experts for the Lesotho Highlands Water Project called for improvements of the living standards of resettled people, the two governments claimed that they wished only to restore living standards to what they were before first disturbance. The government spokespersons pointed out that this approach was in line with World Bank thinking (see Scudder 2005, n.d.; Rich 2013).

As the LHWP progressed, several issues arose between the World Bank, the LHWP, non-government organizations, and project-affected people. One of these issues related to the issue of Free, Prior, and Informed Consent (FPIC). The Bank argued that Free, Prior, and Informed Consultation was necessary, but not consent. People in the highlands of Lesotho who were being affected by the project, on the other hand, said that they not only wanted to be consulted, but they wanted to have a say in issues such as whether or not the project should go forward, what kinds and levels of compensation should be provided to project-affected people, and what kinds of land they should receive in exchange for the land that they lost in the project area. None of these arguments held sway either with the two governments, the Lesotho Highlands Water Commission, or the World Bank.

In order to meet water and energy and economic demands, Lesotho and South Africa had both initiated large-scale and small-scale water development projects. Many of the larger rivers in southern Africa have been dammed. There are nearly 30 dams on the Gariep (Orange) River and nearly the same number on the Limpopo. Table 1 shows some of the 
major dams constructed over the past century in Africa along with some of the social impacts, including resettlement. The construction of the Kariba Dam on the Zambezi River in the mid-1950s led to a massive resettlement effort, with some 57,000 Tonga and others being moved out of the basin, many of them into the plateau region of Zambia (Scudder 1993, 2005; Scudder and Colson 1982, 2002; Clark, Colson, Lee, and Scudder 1995; Harnish, Cutright, Cliggett, and Scudder 2015).

As was shown by the Kariba, Aswan, Merowe, and other large dam projects in Africa, serious problems are experienced by people who are relocated by dams (see Cernea 1995, 1997; Scudder 2005, 2009, 2012; www.internationalrivers.org, accessed 17 March, 2015; Fujikara and Nakayama 2015). Project-affected peoples often are moved into alternative upland areas that are less productive ecologically. As a result, their incomes and agricultural yields often decline, and they have to cope with various kinds of social, psychological, and physiological stresses. In many cases, the people who are relocated are put in a position where they have to become at least partially dependent on food relief and other livelihood supports provided by international relief agencies, state governments, and civil society.

The Lesotho Highlands Water Project had significant impacts on the highland habitats and resident populations. Table 2 shows the numbers of people who were relocated or resettled by the implementation of Phase 1 of the LHWP. It can be seen that some 573 households were affected directly, while an additional 20,000 people were indirectly affected.

Table 1. Major Dams in Africa that Have Affected Local Communities

\begin{tabular}{|c|c|c|}
\hline Name of Dam and Year(s) of Completion & River and Country & $\begin{array}{c}\text { Numbers of Households of Individuals } \\
\text { Displaced or Resettled }\end{array}$ \\
\hline Akosombo Dam, 1965 & Volta River, Ghana & 84,000 people \\
\hline Aswan Dam, 1902, 1912, 1934 & Nile River, Egypt & hundreds of Nubians and others displaced \\
\hline Aswan High Dam, 1970 & Nile River, Egypt and Sudan & 120,000 people $(50,000$ from reservoir area $)$ \\
\hline Gibe III Dam, 2016 (began 2006) & Omo River, Ethiopia & $\begin{array}{l}\text { 32,000 people resettled, half a million affected, } \\
\text { downstream impacts on Lake Turkana }\end{array}$ \\
\hline Kainji Dam, 1968 & Niger River, Nigeria & 44,000 people \\
\hline Kariba Dam, 1959 & Zambezi River, Zambia and Zimbabwe & $\begin{array}{c}57,000 \text { people }(34,000 \text { from reservoir, Zambia } \\
\text { side })\end{array}$ \\
\hline Katse Dam, 1995 & Malibamats'o River, Lesotho & $\begin{array}{c}71 \text { households displaced, } 2,700 \text { hectares } \\
\text { grazing and } 925 \text { ha of arable land lost, } 20,000 \\
\text { people affected }\end{array}$ \\
\hline Kiambere Dam, 1988 & Tana River, Kenya & 7,000 people \\
\hline Maguga Dam, 2001 & Nkomati River, Swaziland & $\begin{array}{c}66 \text { households (ca. } 480 \text { people) displaced, } \\
\text { cultural impacts }\end{array}$ \\
\hline Manantali Dam, 1988 & Bafing River, Mali & 11,000 people $(9,535$ from reservoir $)$ \\
\hline Merowe Dam, 2008 & $4^{\text {th }}$ Cataract of the Nile, Sudan & $\begin{array}{l}70,000 \text { people displaced, some left in desert } \\
\text { with no support or facilities }\end{array}$ \\
\hline Mohale Dam, 2007 & Senqunyane River, Lesotho & $\begin{array}{l}325 \text { households in Stages } 1 \text { and } 2,71 \text { other } \\
\text { households lost over } 50 \% \text { of their land; } \\
1,125 \text { ha of grazing land and } 875 \text { ha of arable } \\
\text { land lost, } 7,400 \text { people affected }\end{array}$ \\
\hline Roseires Dam, 1966 & Blue Nile, Sudan & 10,000 people displaced \\
\hline TOTAL: 1,500 high dams & 54 countries & Over $1,200,000$ displaced \\
\hline
\end{tabular}

Note: Data obtained from fieldwork and from World Commission on Dams (2000); McCully (2001); Scudder (2005) and International Rivers, www.internationalrivers.org

Table 2. Families Relocated or Resettled by Destination and Stage in LHWP Phase 1A and 1B

\begin{tabular}{|c|c|c|c|c|}
\hline Stage & Destination & Foothills & Maseru & Total \\
\hline 1A Katse & Katse Basin & & & 71 \\
\hline 1B Mohale & $\begin{array}{c}71(25 \text { in crash program in } \\
1995)\end{array}$ & 0 & 0 & 99 \\
\hline Stage 1(1996-1998) & Mohale Basin & & & 222 \\
\hline Stage 2 (2002-2006) & 37 & 38 & 24 & 169 \\
\hline $\begin{array}{c}\text { Stage 3 (post inundation, 2006-present) } \\
\text { People Who Lost over 50\% of their land under } \\
\text { Stage 3 }\end{array}$ & 27 & 177 & 18 & 74 \\
\hline Total & 72 & 4 & 0 & 573 relocated, resettled, or affected \\
directly
\end{tabular}

Note: Data obtained from the Lesotho Highlands Development Authority (LHDA). In the Stage 3 (Residual Resettlement) category of Phase 1B, project affected households that lost over $50 \%$ of their arable land were allocated fields in two areas in the Mohale basin, Ha Nthakane and Ha Koporale 


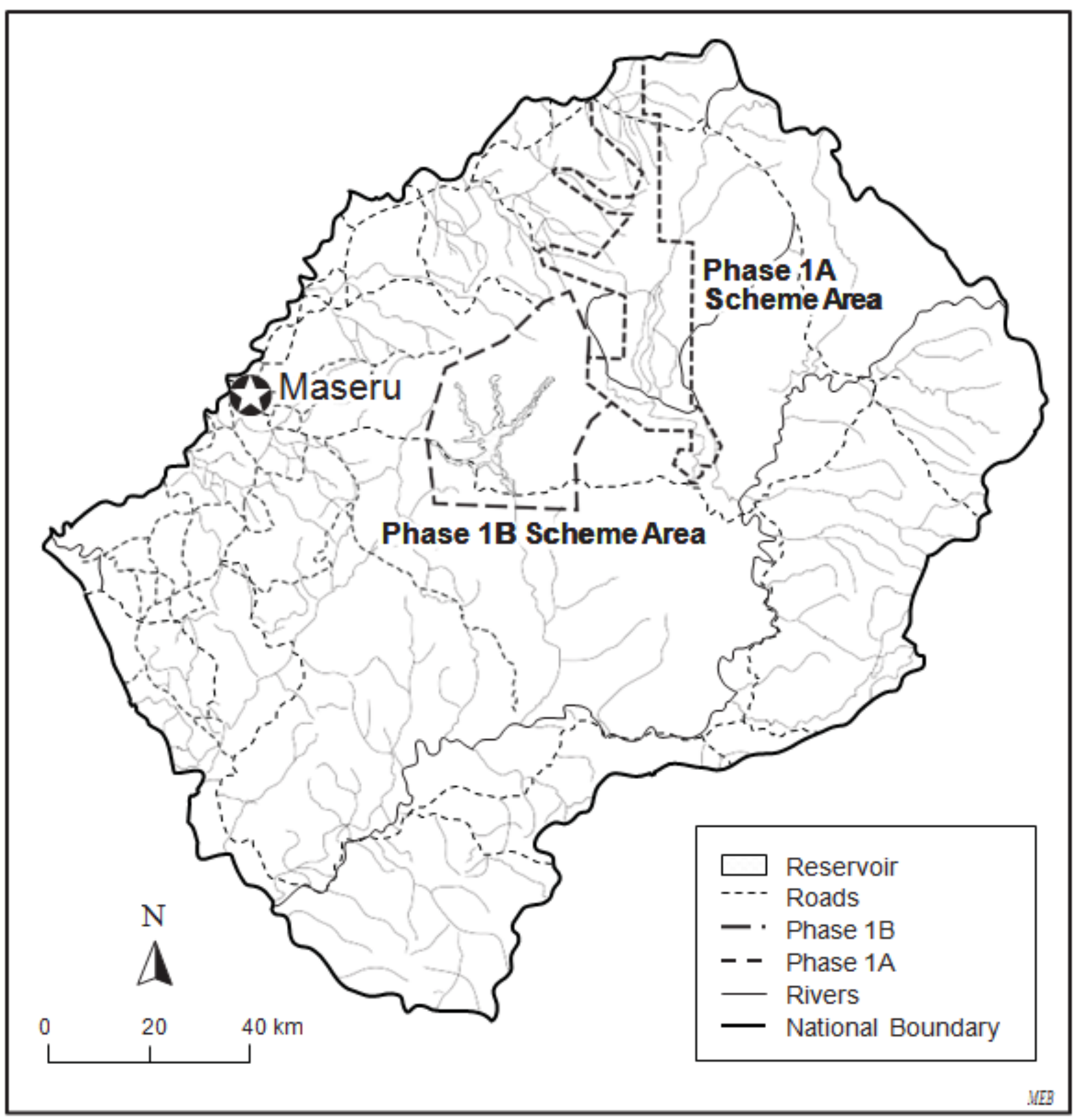

Resettlement is a complicated process, one that is often extremely hard on the people who are relocated. A major problem with development-related resettlement projects is that planners generally have tended to focus attention on loss of residences (i.e. homes) rather than on loss of access to the means of production (especially land, grazing resources, and wild resources on which people depend for subsistence and income). A second major problem is that in nearly all cases, the degree of impact on populations has been seriously underestimated.

The post-resettlement economic indicators of household welfare proved to be very difficult to assess. Reliable evaluations of the cultural, social, spiritual and personal losses are almost entirely missing, and even if these had been investigated and reported, there were few, if any, remedial actions, recommended.

Some losses are irreparable and cannot be made good by the normal means of compensation. Numerous people said, "How can our lives, which were dependent on the soil and on rainfall, be the same if we have no land?" Some also said, "Our lives depended in part on our cattle and sheep; now we do not live close to our animals, and some of them have been stolen."

\section{Unintended Consequences of the LHWP}

One of the unintended consequences of the LHWP was an 
earthquake that occurred in November, 1995 that caused damage in 7 villages around the Katse Reservoir and destroyed 11 homes and, according to local people, caused a crack in the earth at the village of Mapaleng. This earthquake may have been a consequence of reservoir-induced seismicity (RIS) caused by the weight of the water in the Katse Reservoir which had begun to fill in October, 1995. Some local people blamed the project for the earthquake and subsequent seismic activity, while others placed the blame on a large "river snake" that they said had been disturbed by the construction activity in the Katse area.

A second unintended consequence of the LHWP was the drying up of springs in the catchment areas of the project. Such an event occurred, for example, at the village of $\mathrm{Ha}$ Mensel near Katse, close to the Katse Township and administrative offices that were built to oversee the project. It was ironic, villagers said, that there was a large water tank built by LHDA in the village to provide water to the engineers and dam workers and their families in Katse, but they themselves had less access to water now than they did before the project began. Springs also dried up in Ha Lejone, Ha Theko, Ha Soai, Kholontsho, Mphoroshane, and Mapaleng, all in the catchment area of Phase 1A (the Katse Dam and Reservoir).

A third unintended consequence was an increase in HIV/AIDS in the population in the highlands of Lesotho. Estimates of the HIV/AIDS prevalence rate in the project area in the late 1980 s was $0.9 \%$ of the population. Recent figures suggest that the HIV/AIDS prevalence rate was at a level of $22 \%$, which is approximately the rate of urban areas in Lesotho such as Maseru (Human Sciences Research Council 2009; Amusaa Inambao, personal communication, 2014). A question that needs to be addressed is whether the LHWP itself is responsible for the increase in HIV/AIDS, and, if so, what kinds of mitigation measures can be implemented in order to ensure that the project-affected population is at least as well off as they were prior to the inception of the project, in keeping with the treaty obligations between the two governments of Lesotho and South Africa.

A fourth unintended consequence of the project related to cultural and socioeconomic impacts. Some of the people who were resettled felt bereft. While they were able to get cash compensation and have their dead relatives moved to their new locations, they felt that their new ways of life were seriously lacking as compared to what they had experienced prior to the project. According to some of the resettlers, there were fewer traditional ceremonies being conducted in the new locations, and people had to go long distances to take part in cultural activities. The Lesotho Highlands Water Project, they maintained, represented a serious threat to Basotho culture.

A fifth unintended consequence of the LHWP was a major corruption scandal in the early 1990s. Forensic audits revealed problems in the accounting of the Chief Executive of LHDA, Mr. Masupha Sole, and a number of major private companies involved in the construction of the infrastructure.
After a series of corruption trials which were monitored by World Bank and LHDA personnel, the results were as follows ${ }^{1}$

- Masupha Ephraim Sole (former LHDA CE) - fined M8.9 mil + 15 year prison sentence

- Acres (Canadian company) - fined M15 million

- Lahmeyer (German company) - fined M12 million

- Spie Batignolles (French company) - fined M10 million

- Du Plooy (South African individual) - fined M500,000

For the transnational corporations convicted in the bribery scandal, the guidelines of the World Bank required that they not be allowed to compete for contracts involving World Bank funding for 10 years. Some of the companies were among the largest engineering and construction firms in the world. Perhaps not surprisingly, the World Bank did not hold to its own guidelines and allowed some of the companies that had been convicted on corruption charges to compete for and receive World Bank contracts long before the decade-long ban ended.

\section{Economic, Social, Cultural, and Environmental Rehabilitation}

Large-scale water projects like the LHWP almost inevitably have not only economic and environmental impacts but also have significant social, cultural, and gender effects (McCully 1996; Scudder 2005; Fujikara and Nakayama 2015; Tello 2015). This has certainly been the case in the Lesotho Highlands Water Project (see, for example, Braun 2005 and the reports of the Panel of Environmental Experts for the LHWP). Some of the changes that were brought about by the LHWP included the loss of religious sites, the inundation or removal of graves, and the separation of families that had long lived together from one another as a result of resettlement.

For many families physical resettlement was followed by a difficult period of adaptation and uncertainty. The resettled households had simultaneously to reconstruct their sources of household income and their relations with their neighbors, settle their children into new schools, and cope with the loss of culturally significant sites. They also had to learn to manage their new financial situations, which for many had been modified substantially by the substitution of their familiar land and natural resources with cash payments.

The households that moved to Maseru found new opportunities as well as difficulties. On the positive side, some people were able to take advantage of the urban economic opportunities, investing in malaene, rental property located close to the industrial area where there were garment factories. These were flourishing at the time, but by 2005 the massive influx of Chinese-made garments on to the world, as well as Lesotho's, markets and China's admission to the World Trade Organization, led to a major crisis in

1 US $\$ 1=$ M7 (maloti) $=$ R7 (Rand) at the time. 
Lesotho's garment industry. Most factories closed down, leaving large numbers of workers unemployed. This resulted in a decline in the demand for rental accommodation. Some individuals took their lump sum compensation payments and invested in taxis, a highly competitive field. This investment also turned out to not be sustainable for most individuals and households.

One group of people who raised serious questions about the project and the World Bank's approach was the Amatola. Amatola, a term meaning San, is used by some of the people who live in the Maluti-Drakensberg area to refer to themselves (How 1970; Francis 2009; Challis 2012; Mitchell 2012). San descendants sometimes also refer to themselves as Abatwa, the Zulu word for San. The term Abatwa is used by some people in the Maluti Mountains of Lesotho to designate themselves as a distinct people. At the same time, some of them also self-identity as Zulu (Prins 2009:198). Their identity is based on the notion of a primordial past of hunting and gathering, which some residents of the southeast African mountains claim to have.

In southern African stories and oral history, the Abatwa were 'people who live with the ants', that is, people who live in anthills. They are often characterized as 'small people' who use poison arrows. Most of the people who identify themselves as having San ancestry claim that they were indigenous to the region, and say that they are responsible for the thousands of rock paintings and engravings in the mountains and foothills and along the rivers in Lesotho. It is interesting to note that although there were people in the project area who identified as indigenous, the Lesotho Highlands Development Authority and the World Bank failed to mention that there might be an issue affecting indigenous peoples, and no efforts were made by either LHDA or the World Bank to develop an indigenous peoples action plan.

The Lesotho Highlands Water Project and its associated infrastructure affected some rock shelters and open sites which are mostly Middle and Late Stone Age and, to a lesser extent, historic (Kaplan and Mitchell 2012). The LHWP also affected a sizable number of rock art sites. Many of these places are now claimed by Basotho or by Abatwa who say that they are the descendants of people who were occupying the mountains in the $19^{\text {th }}$ century and who were responsible for many of the rock paintings and engravings.

The LHWP provided for environmental rehabilitation, natural resources management and conservation. Efforts were undertaken to conserve endangered species such as the Maloti minnow (Pseudobarbus quathlambae), the bearded vulture (lammergeier, Gypaetus barbarus), and the spiral aloe (Aloe polyphylla). Nevertheless, there were impacts on biodiversity and on habitats. In order to cope with some of these impacts, the project authorities set aside some protected areas, including a new national park, Ts'ehlenyane, in the 'Muela area and the Bokong Nature Reserve, located in the highlands in an alpine ecosystem which is a wetland with rare vegetation. There was also a cultural park that was established in 'Muela, known as Liphofong, which was operated by a Community Conservation Forum (CCF) from the local area.

\section{Resettlement Issues and Project-affected People}

The people who resettled in the capital city of Maseru learned quickly that living costs in the urban area were far higher than in the mountains. The transition from an agricultural and pastoral life to urban life was by no means easy, judging from comments of resettlers. One group who had moved to Makhoakhoeng in Maseru, for example, found that their hosts refused to allow them to bury one of their members who had died there. While this problem was eventually resolved, it was not before there were calls from the hosts for the settlers to be relocated by the Lesotho Highlands Development Authority to another area. Similar kinds of statements were made in other places in the foothills, where there was evidence of disagreements over access to land, water, grazing, and firewood. Phase 1B resettlers moving to the foothills from Mohale had difficulties getting access to land for crops, in part because host populations asked high prices for the land or were reluctant to allow the immigrants to rent or sharecrop or, even more complex, buy land.

Interviews with people who had resettled in the foothills and lowlands or who had relocated in the highlands revealed a variety of views on whether they felt themselves to be better or worse off as a result of the LHWP. Half of the households who had moved to the foothills said that their agricultural yields and commercial sales of agricultural products were now higher. At the same time, they said that their cash expenditures for agricultural inputs such as seeds and fertilizers were far greater. Approximately a fifth of the resettlers that the Panel of Environmental Experts interviewed in the foothills over the past decade responded that being separated from their livestock, most of which had been left in the highlands, had exposed them to higher losses due to theft. Nearly all of the people resettled in the foothills and lowlands said that they now had greater access to social services and markets, but that their costs of living had increased substantially.

The various surveys and reports on the affected families (e.g. Panos Institute 2001; Transformation Resource Center 2004, 2005; Thamae and Pottinger 2006, Human Sciences Research Council 2009) show that the LHWP had widely differing effects on the families who were affected by the project. Some of the resettlers expressed strong views about the effects of the LHWP. As one man, Sebili, said that life in the past was better with good rains. "This land was very good for crops but now it is ... changing and is causing us hunger during these times of drought" (Panos Institute 2001:3). He went on to say that with resettlement "The wisdom of living in this place will be lost" (Panos Institute 2001:4). Some households increased their incomes temporarily by working on the dam, tunnels, feeder roads, or the water and sanitation 
projects carried out in the project area, but these jobs were short-term, and overall, unemployment levels increased in the two Phase 1areas.

The fact that the displaced people ended up in different places, some of which were in new communities in the Mohale Basin and others in the foothills or lowlands, meant that their old communities were completely dismantled. One result of this dismantling was that it was more difficult for the affected families to articulate their shared difficulties and grievances to the authorities. They attempted to do this by going to local level committees, known as Community Area Liaison Committees (CALCS) (though these were later done away with by LHDA); they went to traditional authorities, and some of them made formal appeals to the Lesotho Ombudsman. They also spoke to various non-government organizations working in the area such as the Highlands Church Action Group and the Transformation Resource Center (TRC) who publicized their complaints. Reports were done on the problems faced by the project-affected population (e.g. by International Rivers). In 1998 and 1999 Lesotho and South Africa filed formal complaints about the LHWP with the World Bank Inspection Panel.

Two principles are central to all but a very few internationally financed resettlement programs: (1) that the affected people should in large measure be the architects and the builders of their own futures; and (2) that none of the people who are compelled to move should end up being worse off than before. These principles were fully incorporated into LHDA's 1997 revision of its compensation and rehabilitation policy (Devitt and Hitchcock 2010). The problem was that the lack of baseline data on the various households and communities affected by the project made it almost impossible to determine whether they were worse of, better off, or the same, after the project was implemented.

One of LHDA's legal obligations is to ensure that the LHDA "shall effect all measures to ensure that members of local communities who will be affected by flooding, construction works, or other similar Project-related causes, will be able to maintain a standard of living not inferior to that obtaining at the time of first disturbance' (LHDA Treaty, 1987, p. 27). The LHDA Order of 1986 states that the LHDA shall 'ensure that as far as reasonably possible, the standard of living and the income of persons displaced by the construction of an approved scheme shall not be reduced from the standard of living and the income existing prior to the displacement of such persons.'

Communal compensation in the form of the Rural Development Program for losses of grazing and other natural resources was supposed to be provided to project-affected communities and their hosts. To participate in the RDP people were required to form co-operatives, grazing associations or other kinds of local legal entities. The co-operatives enabled their members to purchase agricultural inputs and to market their products, including seed potatoes and maize; the grazing associations were intended to improve the management of the communal range; grain mills provided a service where none was previously available; other components included tourism, fisheries, health, water and sanitation and youth development

While the individual compensation and threshold payments were intended to ensure that affected families were at least no worse off after than before resettlement, the communal compensation' was meant to bring 'development' and improved standards of living both to the affected families and to their hosts. It was recognized that dislocation of the Mohale communities was likely to have particularly adverse consequences for people with little or no land, for the old and dependent, for sick and disabled people, and even for young people with no land rights. For them compensation for the loss of assets and of production could be quite inadequate to prevent their falling into poverty. The provision for compensating the holders of 'secondary rights' and the Minimum Threshold Payment were designed to prevent this. Despite the difficulties of implementing these policies, they were attempts by the LHDA and the project authorities to avoid harming the weak and the vulnerable.

Table 3. Co-operatives and Local Legal Entities (LLEs) in the LHWP Area

\begin{tabular}{|c|c|c|c|}
\hline Area & Upstream & Downstream & Total \\
\hline $\begin{array}{c}\text { Phase 1A } \\
\text { Katse-Lejone-'Muela }\end{array}$ & 23 & 22 & 45 \\
\hline Phase 1B Mohale & 54 & 32 & 86 \\
\hline & 77 & 54 & 131 \\
\hline
\end{tabular}

LHDA, under its development program, supported a range of institutions and activities including co-operatives, range management associations, and agricultural extension services for the benefit of both the resettlers and their hosts. Table 3 shows the data on the cooperatives and local legal entities formed in the Phase 1A and 1B project areas.

A total of 77 were planned for the Phase 1 upstream area. While some of these cooperatives, including the seed potato and maize growing cooperatives have clearly flourished, others are harder to assess. Cooperatives in general have a record of being complicated to implement in Lesotho, and people tend to be wary of committing their own resources to them. Individuals may enroll as members on a tentative basis, to see if the cooperative brings any tangible benefits, and if not they leave after a year or two. The number of cooperatives established therefore gives no assurance that they will survive or thrive.

While the implementation of some of LHDA's development projects was delayed, a number of project-affected people have been able to benefit from them. Particular progress was made in 2003-2004 in seed potato production, thanks in part to a store with cooling facilities built by funds provided by LHDA and managed by the large farmer's cooperative at Mohale. There was also some success in promoting maize production, in spite of the drought. Many people had started gardens and were growing a wide range of vegetables.

A number of farmers in the project and resettlement areas are diversifying by raising chickens for consumption, sale, and egg production. One farmer was producing a wide 
variety of vegetables (onions, cabbage, and many others) along with apples and peaches that he was selling to neighbours and to teachers and health workers at the local mission hospital. Some cooperative members produce and sell tree seedlings, flowers, vegetables, and fruits. Cooperatives also produce and sell goods such as coffins, face creams, and crafts.

As LHDA's resettlement and compensation program drew to a close, and funding for its various components, including the Rural Development Program, was terminated, the question of sustainability became paramount. Without detailed socioeconomic investigations of the co-operatives and LLEs it is difficult to say how effective they were and whether they had met the needs of communities whose assets were affected by the dams and other infrastructure. It is, however, possible, however, to say that many of the cooperatives were engaging in entrepreneurial enterprises, albeit with mixed success. There were at least 16 different kinds of activities in which cooperatives and LLEs were engaged. The returns on the investment vary considerably, but some of the activities are proving to generate income and enhance livelihoods in other ways (e.g. reducing labor of women through the availability of hammer mills to grind maize, sorghum and other goods).

The business plans of the various cooperatives and of the LLEs required by the LHDA in order to justify release of communal compensation funds varied considerably. Some were very short without much detail. Others were lengthy documents, 20 or more pages, with detailed costing and rates of return. It appears that the variability is due in part to the availability of an experienced income generation officer, Technical Assistance Unit member of the Co-operatives Department who had the time to work with the cooperative or LLE to develop a business plan. The Co-operatives Department of the Ministry of Agriculture was understaffed and the support it was able to offer new cooperatives and LLEs at the early and crucial stages of their development is therefore limited.

An unfortunate turn of events that occurred in 2014 was that that Lesotho Highlands Water Commission and the Lesotho Highlands Development Authority decided not to pay the communal compensation owed to the cooperatives and local legal entities (LLEs) but instead to withhold that compensation, arguing that the communities were doing a poor job of managing the communal compensation funds, and saying that henceforth LHDA would not fund any commercial or income generating initiatives and would require all local legal entities to deal with service providers that were appointed by LHDA (Lesotho Highlands Development Authority Social Development and Environment (SDE) Division 2014). Not surprisingly, the cooperatives and local legal entities in the upstream and downstream areas of the camps did not agree with this decision, as they felt it violated the Constitution of Lesotho and the LHWP Treaty and Order. At least one LLE opted to take LHDA to court. The legal judgment on this matter remains outstanding.
The compensation and development issues were exacerbated by the fact that some of the project-affected people were worse off after the completion of the project than they were before the LHWP began. Greater vulnerability to crop failure and reduced crop yields were mentioned by a number of Basotho in the project area and in the resettlement locations. Concern was also expressed about lower incomes and higher rates of poverty. Some of them spoke of issues relating to fishing, which, they said, was harder now in Katse reservoir. It was also noted that even the large-scale fisheries pilot projects, one of them led by a company known as Katse Fresh Fish, was having problems with fish production. These occurred, for example, when the trout cages were broken by high winds on the reservoir surface, releasing caged trout into the reservoir, or when there were die-offs of fish due to high temperatures and lowered water levels.

Local fishermen and women said told researchers and Panel of Environmental Experts members that it was harder to get fish in some of the rivers than it used to be, in spite of the fact that there was a Lesotho Highlands Development Authority-sponsored fisheries project and people were encouraged to take advantage of the fisheries opportunities. The LHDA fishing projects, however, wound down by the beginning of the new millennium.

Local informants also said that wild medicinal and food plants were less accessible than was the case in the past. Some of this, they said, was because there were more people in smaller areas in the highland using these resources, making them harder to find. They also said that local-level habitat changes and population increases in some areas were responsible for the shifts in economically and ritually important plant availability.

Lesotho has used both cash and land-for-land types of compensation approaches (Slater and Mphale 2009; Devitt and Hitchcock 2010). It has also employed a development-related approach. While there are questions as to whether the cash compensation approach led to people being better off after they were moved than before (compare Human Sciences Research Council 2009 with other analyses of the Lesotho Highlands Water Project, notably Tshabalala and Kisubi 2001; Scudder 2005, 2006; Devitt and Hitchcock 2010; Meissner 2015). it is apparent that a diversified approach that emphasizes sustainable development is the approach that works most successfully.

The Lesotho Highlands Water Project was the largest water-related infrastructure project of its kind in Africa at the time of its implementation. It has since been eclipsed by other large-scale water projects in Africa, including the Meroe Dam on the $4^{\text {th }}$ Cataract of the Nile in Sudan and the Gibe III dam project on the Omo River in southwestern Ethiopia. For comparative purposes, it is useful to look at Asia, where there has been a huge increase in the number of large dams in the past two decades, especially in China and India but also in southeast Asia (Leslie 2005; Fujikura, Mikiyasu, and Takesada 2009; Oliver-Smith 2009, 2010; Tortajada, Altinbilek, and Biswas 2012; Grumbine and Panit 
2013; Rich 2013; Kuenzer et al 2014; Singer and Hoang 2014-2015; Tello 2015). There are a number of lessons that have been learned as a result of recent experiences with dam construction in Asia (see Table 4 for some dams built in the past decade in Asia along with their impacts). First, in virtually all cases, the impacts on the project-affected people were greater than were estimated by the consultants doing the environmental and social impact assessments on the dam projects. Second, there were problems with the consultation and participation processes employed in all of the projects, even ones such as Nam Theun 2 that were cited by the World Bank and others as being cutting edge projects (Guttal and Shoemaker 2004; Lawrence 2009; Porter and Shivakumar 2011; Baird, Shoemaker, and Manoram 2015; International Rivers 2015; Scudder n.d.). The downstream impacts in all of the projects were greater than estimated by the contractors working on the dam projects (see, for example Richter et al 2010; Oliver-Smith 2010; Scudder 2012). The quality of social and environmental impact assessments has gone down considerably in the past decade, due in part to the rush to get dam projects approved for funding (Chavkin et al 2015). This can be seen, for example, in the way that the Asian Infrastructure Investment Bank (AIIB) laid out its environmental and social framework consultation draft circulated on 3 August, 2015 and in the watered-down safeguards policies of the World Bank disseminated in early 2015.

From the analysis of the social and environmental impacts of dams in Asia, it is clear that (1) the environmental, social, and economic costs were much greater than the benefits that accrued to the resettled and project-affected people; (2) the project financial costs in the final analysis were much higher than had been estimated in all of the projects (in other words, cost over-runs were significant, raising questions about the quality of the financial analysis of the projects; (3) the numbers of people who were resettled or affected were in all cases greater than had been estimated at the outset, suggesting that the quality of the initial surveys that were done were inadequate, (4) the downstream impacts of the project were in all cases greater than envisioned originally, calling into question the quality of the surveys that were done, (5) the degree to which there was impoverishment of the displaced population was much greater than had been anticipated; (6) the quality of life for many of the displaced people had declined considerably, and planned mitigation efforts were in virtually all cases less than needed by the project-affected people. The psycho-social impacts were much greater than was anticipated in much of the displaced and resettled population, but little consideration was given by project authorities about how to deal with these impacts. This was true also for dams in Africa and Latin America (Ledec and Quintero 2003; Tello 2015). Clearly, there has to be significant improvements in the ways in which the social and environmental impacts of dam projects are assessed, and there must be stronger safeguards put in place than exist at present.

Table 4. Major Dams in Asia that have Affected Local Communities

\begin{tabular}{|c|c|c|}
\hline $\begin{array}{c}\text { Name of Dam and Year(s) of Initiation and/or } \\
\text { Completion }\end{array}$ & River and Country & $\begin{array}{l}\text { Numbers of Households or Individuals } \\
\text { Displaced or Resettled } \\
\end{array}$ \\
\hline Arun III, 1992 & Arun River, Nepal & $\begin{array}{c}775 \text { people displaced, reservoir } 43 \text { hectares in } \\
\text { size }\end{array}$ \\
\hline Bakun Dam, 2000 & Borneo, Malaysia, mostly state funded & $\begin{array}{c}\text { Toxic impacts, removals of Penan indigenous } \\
\text { people }\end{array}$ \\
\hline $\begin{array}{l}\text { Dahla (Arghandab) Dam, 1954, additions, } \\
\text { 2012-present }\end{array}$ & Arghandab River, Kandahar, Afghanistan & $\begin{array}{l}\text { Estimated } 25 \text { households will be resettled as a } \\
\text { result of the heightening of the dam wall }\end{array}$ \\
\hline Nam Nguni, 2007 & $\begin{array}{l}\text { Lao People's Democratic Republic (Laos), } \\
\text { state funded }\end{array}$ & 3,000 people displaced, 37,000 ha reservoir \\
\hline Nam Theun 2 (NT2) dam, commissioned 2010 & $\begin{array}{l}\text { Xe Bang Fai River, Lao People's Democratic } \\
\text { Republic (Laos); World Bank and Asian } \\
\text { Development Bank and private funding, one of } \\
\text { the largest internationally financed project in } \\
\text { Asia } \\
\end{array}$ & $\begin{array}{l}6,300 \text { resettled so far, of an estimated } 10,000 \\
\text { total, some of them hunter-gatherers; } \\
40,000-150,000 \text { total project- affected people }\end{array}$ \\
\hline Nam Theun-Hinboun, 2011 & $\begin{array}{c}\text { Nan Theun Hinboun River, Lao People's } \\
\text { Democratic Republic (Laos) }\end{array}$ & $\begin{array}{c}630 \text { ha reservoir, an estimated } 4,000 \\
\text { project-affected people }\end{array}$ \\
\hline $\begin{array}{l}\text { Sardar Sarovar Dam, and other Narmada Dams, } \\
1990 \text { and on-going }\end{array}$ & Narmada River, India & $\begin{array}{l}\text { Estimated } 100,000 \text { people resettled, } 140,000 \\
\text { people affected by infrastructure, canals, } \\
\text { irrigation systems, } 90,820 \text { ha reservoir }\end{array}$ \\
\hline
\end{tabular}

Note: Data obtained from fieldwork and from World Commission on Dams (2000); the International Commission on Large Dams; McCully (2001); Scudder (2005); World Bank (2013); http://www.dams.org and International Rivers http://www.internationalrivers.org 


\section{Conclusions}

There are a number of lessons to be learned from the Lesotho Highlands Water Project experiences that are applicable to dam and infrastructure projects in other areas of the world.

First, the success of large dam and water transfer project and resettlement activities are dependent upon transparency, openness, accountability, and flexibility.

Second, in order to determine whether communities, households, and individuals are better off, the same, or worse off as a result of project activities, it is necessary to get detailed baseline data against which changes can be monitored and measured. Social impact assessments done as part of safeguards policies should ensure that various categories of people are interviewed and monitored, breaking the population down along gender, age, class, ethnic, occupational, vulnerability and other lines.

Third, it is necessary to have a policy environment that is appropriate and positive for all concerned, one which takes into careful consideration international, regional, national, and local level policies and practices and places significant emphasis on local culture, heritage, and traditions. Parties involved in dam construction and water resource management project formulation must pay close attention to the social, political, economic, and environmental situations in the project areas.

Fourth, no matter how good a development policy is, it is likely to fail if it goes against the interests of the local populations and if local people are not involved in decision-making and planning. Public participation, therefore, is crucial to the success of large-scale water projects. Free, Prior, and Informed Consent (FPIC) should include not just consultation but meaningful information dissemination, local-level discussion, and real consent.

Fifth, in the case of some other large dam projects (e.g. Nam Theun 2 in Laos), particularly useful were the efforts of the project authorities, consultants, non-government organizations, researchers, civil society, and a panel of environmental experts (POE) to monitor and evaluate the project as it went forward. These evaluations must take into consideration such diverse topics as the social effects of projects, poverty indicators, nutrition, health, in-stream flow requirements (IFRs), natural resource accounting, sedimentation, vegetation studies, fisheries, dam infrastructure and engineering, and water quality.

Sixth, one of the areas where significant progress had been made in the past was in the rules and procedures relating to involuntary relocation or resettlement resulting from the establishment of large-scale water infrastructure projects (World Bank 2001; Scudder 2005). An issue with the World Bank now is that the Bank is reducing their safeguards when it comes to environmental, social, and resettlement issues, in line with some current thinking on being less regulatory and more market-oriented (Chavkin et al 2015). Given the experiences of large dam projects in Africa, Asia, and Latin America this will have negative impacts on people and habitats around the world. Involuntary resettlement policies of all of the world's agencies doing resettlement must be improved and strengthened as must the performance standards for social and environmental sustainability (see, for example, World Bank 2004; International Finance Corporation 2012 and the safeguards policies of the World Bank, the Asian Development Bank, the African Development Bank, and private sector transnational invest-finance banks). The scholarly community should be consulted in this effort along with states, non-government organizations, and institutions such as the Lesotho Highlands Development Authority.

Seventh, as is often the case with reporting on the outcome of a resettlement program, the people who have made a conspicuous success of the opportunities offered by dam-related project activities are relatively few in number but are the ones that World Bank officials and project authorities tend to focus on because of their success. In a few cases these individuals, if they are identified, are held up by the project authorities as examples of how well the project has worked. Those who have fared less well, however, are easily lost from sight except in situations where determined efforts were made to locate them. Interviews with members of what were defined as vulnerable households, those who were extremely poor, female-headed and child-headed households, households made up of people who were elderly or physically incapacitated, or who otherwise were at risk indicated that they many of them were fearful about the future and were uncertain how they were going to make a living in the face of all the changes that had occurred in their lives.

Eighth, the post-resettlement economic indicators of household welfare have proved very difficult to document and assess. Reliable evaluations of the cultural, social, spiritual and personal losses are almost entirely missing, and had these been investigated and reported there were few, if any, remedial actions, recommended. Some losses are irreparable and cannot be made good by means of cash compensation. Thus, much greater attention needs to be paid to baseline data collection, monitoring, evaluation, and assessment of the long-term impacts of projects.

Ninth, greater care needs to be taken in measuring the health and nutritional impacts of large dam projects. Often baseline studies are not done, for example, of disease burdens such as HIV/AIDS, other sexually transmitted diseases, tuberculosis, malaria, schistosomiasis (bilharzia), river blindness, and other diseases. These baseline studies need to be carried out, and monitored throughout the project. Health-related costs need to be built into World Bank projects in a more concerted way.

Tenth, iindigenous and minority and tribal peoples are affected significantly by dam projects. Local people, some of whom are indigenous, have said that residents of these areas have managed them in productive ways for generations and that they should have the right to remain there and to use natural resources. This position is often supported by indigenous rights organizations and social scientists. Some 
countries, including most of those in Africa and Asia, however, do not accept the designation 'indigenous people' (Erni 2008). As a result, they are unlikely to want to ensure that people who self-identify as indigenous are catered for in the social and environmental assessments and baseline data collection relating to hydropower and water transfer projects. These countries must not be allowed to 'opt out' from requirements relating to protections of indigenous peoples, minorities, and vulnerable ethnic groups. Indigenous peoples and other groups should be treated equitably and justly in all dam-related resettlement projects.

Eleventh, people in dam project areas must be informed of the likelihood of Reservoir-Induced Seismicity (RIS) and plans must be made by the project authorities to cope with earthquakes and seismic activity. There must also be plans for emergency evacuation built into all dam projects. Project-affected people must have access to information on those emergency procedures, and there must be early warning systems in place.

Twelfth, much greater attention must be paid to issues of corruption and misdirection of finance in large-scale dam projects. The World Bank's actions on the corruption issues in Lesotho had relatively good effect. However, the companies involved in the corrupt practices should have received greater sanctions. The World Bank, the International Finance Corporation, the European Union and other institutions need to pay greater attention to corrupt practices of states, project authorities, consultants, and transnational corporations

Finally, the social, environmental, and sustainability frameworks of international, regional, and national institutions involved with dams and resettlement must be improved and institutions held to account regarding project needs assessments, baseline data collection, consultation, planning, implementation, monitoring and evaluation and post-project mitigation of negative effects.

\section{Acknowledgements}

Support for the research upon which this paper is based was provided as part of the work of the Panel of Environmental Experts (POE) of the Lesotho Highlands Development Authority and by the Millennium Challenge Account-Lesotho. I would like to thank the governments of Lesotho and South Africa, the LHDA, the World Bank, the Millennium Challenge-Account-Lesotho, the various non-government organizations working on issues revolving around the Lesotho Highlands Water project, and the people of Lesotho and South Africa for their help and their useful information. Junior Patloane, Lebohang Moleko, Richard Ramoeletse, Trower Namani, Masilo Phakoe, Keketso Sefeane, Tankiso Makara, Taole Tesele, Mike Mentis, John Ledger, Amusaa Inambao, Michael Cernea, Ted Scudder, Jonathan Jenness, Andrew Macoun, Roxanne Hakim, Cyprion Fisi, Yehuda Danziger, Jack Hennessy, Fiona Darroch, Stephen Turner, Jane Tomlinson, Ted Downing,
Paul Devitt, Julie Maldonado, Dolores Koenig, Barbara Rose Johnston, Rodolfo Tello, Ryo Fujikura, Chris De Wet, Maria Sapignoli, and the late Dan Aronson provided useful information, ideas, and criticism.

\section{REFERENCES}

[1] Asian Infrastructure Investment Bank (AIIB) (2015) Environmental and Social Framework: Consultation Draft, 3 August 2015.

[2] Baird, Ian G., Bruce P. Shoemaker, and Kanokwan Manorom (2015) The People and their River, the World Bank, and the Dam: Revisiting the Xe Bang Fai River in Laos. Development and Change 46(3):1080-1105.

[3] Bardhill, John E. and James H. Cobbe (1985) Lesotho: Dilemmas of Dependence in Southern Africa. Boulder: Westview Press.

[4] Braun, Yvonne (2005) Feminist Political Ecology in South Africa: The Social Impacts of the Lesotho Highlands Water Project. Unpublished Ph.D. dissertation, University of California, Irvine.

[5] Cernea, Michael M. (1995) Understanding and Preventing Impoverishment from Displacement: Reflections from the State of Knowledge. Journal of Refugee Studies 8(3):245-264.

[6] Cernea, Michael M. (1997) The Risks and Reconstruction Model for Resettling Displaced Populations. World Development 25(10):1569-1587.

[7] Cernea, Michael M. and Hari Mahan Mathur, eds. (2008) Can Compensation Prevent Impoverishment? Reforming Resettlement through Investments and Benefit-Sharing. New York and Oxford: Oxford University Press.

[8] Cernea, Michael M. and Christopher McDowell, eds. (2000) Risks and Reconstruction: Experiences of Resettlers and Refugees. Washington, D.C.: The World Bank.

[9] Chakela, Q.K., ed. (1999) State of the Environment in Lesotho. Maseru: National Environment Secretariat, Ministry of Environment, Gender, and Youth Affairs.

[10] Challis, Sam (2012) Creolisation on the Nineteenth Century Frontiers of Southern Africa: A Case Study of the Amatola 'Bushmen' in the Maloti-Drakensberg. Journal of Southern African Studies 38(2):265-280.

[11] Chavkin, Sasha, Ben Hallman, Michael Hudson, Cecelie Schlis-Gallego, and Shane Shifflett (2015). How the World Bank Breaks its Promise to Protect the Poor. 16 April, 2015, Washington, D.C.: Center for Public Integrity.

[12] Chenje, Munyaradzi and Phyllis Johnson, eds. (1996) Water in Southern Africa. Maseru, Lesotho and Harare, Zimbabwe: Southern African Development Community, IUCN (the World Conservation Union) and the Southern African Research and Documentation Center.

[13] Clark, S.J., E. Colson, J. Lee, and T. Scudder (1995) Ten Thousand Tonga: A Longitudinal Anthropological Study from Southern Zambia, 1956-1991. Population Studies 49(1):91-109. 
[14] Devitt, Paul (1969) Lesotho Social Life and Customs. Masters thesis, University of the Witwatersrand, Johannesburg, South Africa.

[15] Devitt, Paul and Robert K. Hitchcock (2010) Who Drives Resettlement? The Case of Lesotho's Mohale Dam. African Study Monographs 31(2):57-106.

[16] Erni, Christian, ed. (2008) The Concept of Indigenous Peoples in Asia: A Resource Book. Copenhagen: International Work Group for Indigenous Affairs.

[17] Fujikara, Ryo, Nakayama Mikiyasu, and Naruhiko Takesada (2009) Lessons from Resettlement Caused by Large Dam Projects: Case Studies from Japan, Indonesia and Sri Lanka. International Journal of Water Resources Development 25(3):407-418.

[18] Ferguson, James (1994) The Anti-Politics Machine: 'Development,' Depoliticization, and Bureaucratic Power in Lesotho. Minneapolis and London: University of Minnesota Press.

[19] Francis, Michael (2009) Silencing the Past: Historical and Archaeological Colonisation of the Southern San in KwaZulu-Natal, South Africa. Anthropology Southern Africa 32(3\&4):106-116.

[20] Fujikara, Ryo and Mikiyasu Nakayama (2015) Resettlement Policy in Large Development Projects. London and New York: Routledge.

[21] Gill, Stephen J. (1993) A Short History of Lesotho. Morija, Lesotho: Morija Museum and Archives.

[22] Government of Lesotho (1986) The Lesotho Highlands Development Authority Order 1986. Maseru, Lesotho: Government of Lesotho.

[23] Government of Lesotho and Government of South Africa (1986) Treaty on the Lesotho Highlands Water Project between the Government of the Kingdom of Lesotho and the Government of the Republic of South Africa. Maseru, Lesotho: Government of Lesotho and Pretoria and Cape Town, South Africa: Government of the Republic of South Africa.

[24] Grumbine, R. Edward and Maharaj K. Panit (2013) Threats from India's Himalaya Dams. Science 339:36-37.

[25] Guttal, S. and B. Shoemaker (2014) Manipulating Consent: The World Bank and Public Consultation in the Nam Theun 2 Hydroelectric Project. Watershed 10(1):18-25.

[26] Harnish, Allison, Chelsea Cutright, Lisa Cliggett, and Thayer Scudder (2015) Those Who Forget the Errors of the Past are bound to Repeat Them: Field Research on the Impoverishment Legacy of the Kariba Dam Fifty Years Later. Paper presented in a symposium entitled 'Hydropower Dams, Mines, Infrastructure, and Resettlement Safeguard Policies,' Robert K. Hitchcock, Chair. $75^{\text {th }}$ annual meetings of the Society for Applied Anthropology (SfAA), Pittsburgh, Pennsylvania, 24-28 March, 2015.

[27] How, Marion Walsham (1970) The Mountain Bushmen of Basutoland. Pretoria: J. L. Van Schaik, Ltd.

[28] Human Sciences Research Council (2009) Socio-economic, Health, and Nutrition Survey in the Lesotho Highlands Water Project Areas, Volume 1: Main Report. Contract 1204, LHDA. Pretoria: Human Sciences Research Council and Maseru, Lesotho Highlands Development Authority.
[29] International Finance Corporation (2012) IFC Performance Standards of Environmental and Social Sustainability. Washington, D.C.: International Finance Corporation (IFC).

[30] International Rivers (2015) The World Bank and Dams, Part 2: Dispelling Myths of Nam Theun 2. Berkeley: International Rivers.

[31] Kaplan, Jonathan and Peter Mitchell (2012) The Archaeology of the Lesotho Highlands Water Project, Phases 1A and 1B. Southern African Humanities 24:1-32.

[32] Kuenzer, C., I. Campbell, M. Roch, P. Leinenkugel, V.Q. Tuan and S. Dech (2013) Understanding the Impacts of Hydropower Developments in the Context of Upstream-Downstream Relations in the Mekong River Basin. Sustainability Science 8(4): 565-84.

[33] Lawrence, S. (2009) The Nam Theun 2 Controversy and Its Lessons for Laos. In Contested Waterscapes in the Mekong Region: Hydropower, Livelihoods, and Governance, F.F. Molle, T. Foran, and M.K'ak'onen, eds. pp. 81-110. London: Earthscan.

[34] Ledec, George and Juan David Quintero (2003) Good Dams and Bad Dams: Environmental Criteria for Site Selection of Hydroelectric Projects. Latin American and Caribbean Region, Sustainable Development Working Paper 16. Washington, D.C.: World Bank.

[35] Leslie, Jacques (2005) Deep Water: The Epic Struggle Over Dams, Displaced, and the Environment. New York: Farrar, Strauss, and Giroux.

[36] Lesotho Highlands Development Authority Social Development and Environment (SDE) Division (2014) Communal Compensation Communal Compensation Strategy. Maseru: Lesotho Highlands Development Authority.

[37] McCully, Patrick (2001) Silenced Rivers: The Ecology and Politics of Large Dams. Second Edition. London and Atlantic Highlands, New Jersey: Zed Books.

[38] McDowell, Christopher, ed. (1996) Understanding Displacement: The Consequences of Development-Induced Displacement. Providence, Rhode Island and Oxford: Berghahn Books.

[39] Meissner, Richard (2015) Interest Groups, Water Politics, and Governance: The Case of the Lesotho Highlands Water Project. New York: Springer.

[40] Mentis, Mike and John Ledger (n.d.) River Management by Objective. Unpublished manuscript in the possession of the authors.

[41] Mitchell, Peter (2010) Making History at Sehongong: Soal and the Last Bushman Occupants of His Shelter. Southern African Humanities 22:149-170.

[42] Murray, Colin (1981) Families Divided: The Impact of Migrant Labour in Lesotho. Cambridge: Cambridge University Press.

[43] Oliver-Smith, Anthony, ed. (2009) Development and Dispossession: The Crisis of Forced Displacement and Resettlement. Santa Fe: School for Advanced Research Press.

[44] Oliver-Smith, Anthony (2010) Defying Displacement: Grassroots Resistance and the Critique of Development. Austin: University of Texas Press. 
[45] Panel of Environmental Experts, Lesotho Highlands Water Project (1989-2012) Reports on the Lesotho Highlands Water Project, Phase $1 A$ and $1 B$. Maseru, Lesotho: Lesotho Highlands Development Authority.

[46] Panos Institute (2001) Voices from the Mountain: Oral Testimonies from the Lesotho Highlands. London: Panos Institute.

[47] Porter, I.C. and J. Shivakumar, eds. (2011) Doing a Dam Better: The Lao People's Democratic Republic and the Story of Nam Theun 2. Washington, D.C. The World Bank.

[48] Prins, Frans (2000) Forgotten Heirs: The Archaeological Colonization of the Southern San: Native Title and the Transformation of Archaeology in the Postcolonial World. In Native Title and the Transformation of Archaeology in the Post-Colonial World, I. Lilly, ed. Oceania 50:138-152.

[49] Prins, Frans (2009) Secret San of the Drakensberg and Their Rock Art Legacy. Critical Arts 23(2):198-2008.

[50] Rich, Bruce (2013) Foreclosing the Future: The World Bank and the Politics of Environmental Destruction. Washington, Covelo, and London: Island Press.

[51] Richter, B.D., S. Postel, C. Revenga, T. Scudder, B. Lehner, A. Churchill, and M. Chow (2010) Lost in Development's Shadow: The Downstream Human Consequences of Dams. Water Alternatives 3(2):14-42.

[52] Scudder, Thayer (1993) Development-Induced Relocation and Refugee Studies: 37 Years of Change and Continuity among Zambia's Gwembe Tonga. Journal of Refugee Studies 6(2):123-152.

[53] Scudder, Thayer (2005) The Future of Large Dams: Dealing with Social, Environmental, Institutional and Political Costs. London: Earthscan.

[54] Scudder, Thayer (2009) Resettlement Theory and the Kariba Case: An Anthropology of Resettlement. In Development and Dispossession: The Crisis of Forced Displacement and Resettlement, Anthony Oliver-Smith, ed. Pp. 25-47. Santa Fe: School for Advanced Research.

[55] Scudder, Thayer (2012) Resettlement Impacts of Large Dams. In Impacts of Large Dams: A Global Assessment, Cecelia Tortajada, Dogan Altinbelek, and Asit K. Biswas, eds. pp. 37-67. Berlin and Heidelberg: Springer-Verlag.

[56] Scudder, Thayer (n.d.) The Lesotho Highlands Water Project (2003) and Laos' Nam Theun 2 Dam (2003 with 2005 Updating. Unpublished manuscript in Author's Possession.

[57] Scudder, Thayer and Elizabeth Colson (1982) From Welfare to Development: A Conceptual Framework for the Analysis of Dislocated People. In Involuntary Migration and Resettlement: The Problems and Responses of Dislocated People, Art Hansen and Anthony Oliver-Smith, eds. pp. 267-287. Boulder, Colorado: Westview Press.

[58] Scudder, Thayer and Elizabeth Colson (2002) Long-term Research in the Gwembe Valley, Zambia. In Chronicling Cultures: Long-term Field Research in Social Anthropology,
Robert V. Kemper and Anya Peterson Royce, eds. Pp. 197-238. Walnut Creek, California: AltaMira Press.

[59] Showers, Kate B. (2005) Imperial Gullies: Soil Erosion and Conservation in Lesotho. Athens: Ohio University Press.

[60] Singer, Jane and Haj Hoang (2014-2015) Participation in Resettlement Decision-making by Dam-Displaced Villagers in Central Vietnam. Asia Journal of Global Studies 6(1):16-29.

[61] Slater, Rachel and Matseliso Mphanle (2009) Compensation, Welfare, and Development: One-off Lump-Sum and Regular Transfers in the Lesotho Highlands Water Project. London: Overseas Development Institute.

[62] Tello, Rodolfo (2015) Social Safeguards: Avoiding the Unintended Impacts of Development. Arlington, Virginia: Amakella Publishing.

[63] Thamae, M. L. and L. Pottinger (eds.) (2006) On the Wrong Side of Development: Lessons Learned from the Lesotho Highlands Water Project. Maseru, Lesotho: Transformation Resource Centre.

[64] Toratajada, Cecilia, Dogan Altinbelek, and Asit K. Biswas, eds. (2012) Impacts of Large Dams: A Global Assessment. Berlin and Heidelberg: Springer-Verlag..

[65] Transformation Resource Centre (2004) The Irony of the 'White Gold.' Maseru, Lesotho: Transformation Resource Centre.

[66] Transformation Resource Centre (2005) Lives of Resettled Communities after Resettlement: A Survey on the Lives of Communities Affected by the Lesotho Highlands Water Project. Maseru, Lesotho: Transformation Resource Centre.

[67] Tshabalala, Mavuso and Wilson Kisubi (2003) Socioeconomic Monitoring of Households Affected by Phase 1 of Lesotho Highlands Water Project: A Synthesis of 2000/01 Results. Maseru, Lesotho: Lesotho Highlands Development Authority.

[68] World Bank (2001) Involuntary Resettlement. In The World Bank Operational Manual. Operational Policies 4.12, World Bank, ed. Washington, D.C.: World Bank.

[69] World Bank (2004) Involuntary Resettlement Sourcebook: Planning and Implementation in Development Projects. Washington, D.C.: World Bank.

[70] World Bank (2005) Indigenous Peoples. In The World Bank Operational Manual. Operational Policies 4.10, World Bank, ed. Pp. 1-13. Washington, D.C.: World Bank.

[71] World Bank (2007) Implementation Completion and Results Report (IBRD-43390) on a Loan in the Amount of US\$45 Million to the Lesotho Highlands Development Authority for Lesotho Highlands Water Project - Phase 1B. Report No. ICR 168. Washington DC: World Bank.

[72] World Commission on Dams (2000) Dams and Development: A New Framework for Decision-making. The Report of the World Commission on Dams. London: Earthscan Publications.

i An earlier version of this paper was presented at the $75^{\text {th }}$ annual meetings of the Society for Applied Anthropology in a symposium entitled 'Hydropower Dams, Mines, Infrastructure, and Resettlement Safeguard Policies', Robert K. Hitchcock, organizer and chair, Society for Applied Anthropology 75, Pittsburgh, Pennsylvania, 24-28 March, 2015. 